\title{
Plants from the abandoned Nacozari mine tailings: evaluation of their phytostabilization potential
}

\author{
Alina E Santos ${ }^{1}$, Rocio Cruz-Ortega ${ }^{2}$, Diana Meza-Figueroa ${ }^{3}$, Francisco M Romero ${ }^{4}$, Jose Jesus Sanchez- \\ Escalante $^{5}$, Raina M Maier ${ }^{6}$, Julia W Neilson ${ }^{6}$, Luis David Alcaraz ${ }^{7}$, Francisco E Molina Freaner ${ }^{\text {Corresp. }{ }^{1,8}}$ \\ ${ }^{1}$ Departamento de Ecología de la Biodiversidad, Instituto de Ecología, Universidad Nacional Autónoma de México, Hermosillo, Sonora, Mexico \\ 2 Departamento de Ecologia Funcional, Instituto de Ecologia, Universidad Nacional Autónoma de México, Ciudad de Mexico, Mexico \\ 3 Departamento de Geologia, Universidad de Sonora, Hermosillo, Sonora, Mexico \\ 4 Departamento de Geoquimica, Instituto de Geologia, Universidad Nacional Autónoma de México, Ciudad de Mexico, Mexico \\ 5 Herbario USON, Departamento de Investigaciones Cientificas y Tecnologicas, Universidad de Sonora, Hermosillo, Sonora, Mexico \\ 6 Department of Soil, Water and Environmental Science, University of Arizona, Tucson, Arizona, United States \\ 7 Laboratorio Nacional de Ciencias de la Sostenibilidad, Instituto de Ecologia, Universidad Nacional Autónoma de México, Ciudad de Mexico, Mexico \\ 8 Estacion Regional del Noroeste, Instituto de Geologia, Universidad Nacional Autónoma de México, Hermosillo, Sonora, Mexico \\ Corresponding Author: Francisco E Molina Freaner \\ Email address: freaner@unam.mx
}

Phytostabilization is a remediation technology that uses plants for in-situ stabilization of contamination in soils and mine tailings. The objective of this study was to identify native plant species with potential for phytostabilization of the abandoned mine tailings in Nacozari, Sonora in northern Mexico. A flora of 42 species in 16 families of angiosperms was recorded on the tailings site and the abundance of the most common perennial species was estimated. Four of the five abundant perennial species showed evidence of regeneration: the ability to reproduce and establish new seedlings. A comparison of selected physicochemical properties of the tailings in vegetated patches with adjacent barren areas suggests that $\mathrm{pH}$, electrical conductivity, texture, and concentration of potentially toxic elements do not limit plant distribution. For the most abundant species, the accumulation factor for most metals was $<1$, with the exception of $\mathrm{Zn}$ in two species. A short-term experiment on adaptation revealed limited evidence for the formation of local ecotypes in Prosopis velutina and Amaranthus watsonii. Overall, the results of this study indicate that five native plant species might have potential for phytostabilization of the Nacozari tailings and that seed could be collected locally to revegetate the site. More broadly, this study provides a methodology that can be used to identify native plants and evaluate their phytostabilization potential for similar mine tailings. 
1 Plants from the abandoned Nacozari mine tailings: evaluation of their phytostabilization

2 potential.

3 Alina Santos ${ }^{1}$, Rocio Cruz-Ortega ${ }^{2}$, Diana Meza-Figueroa ${ }^{3}$, Francisco M. Romero ${ }^{4}$, Jesus

4 Sanchez-Escalante ${ }^{5}$, Raina M. Maier 6 , Julia W. Neilson ${ }^{6}$, Luis David Alcaraz ${ }^{7}$ and Francisco

5 Molina-Freaner ${ }^{1,8,9}$.

$6{ }^{1}$ Departamento de Ecologia de la Biodiversidad, Instituto de Ecologia, Universidad Nacional

7 Autonoma de Mexico, Apartado Postal 1354, Hermosillo, Sonora C.P. 83000 MEXICO.

$8{ }^{2}$ Departamento de Ecologia Funcional, Instituto de Ecologia Universidad Nacional Autonoma de

9 Mexico (UNAM), Apartado Postal 70-275, Mexico D.F., C.P. 04510, MEXICO

$10{ }^{3}$ Departamento de Geologia, Universidad de Sonora, Rosales y Luis Encinas, Hermosillo, Sonora

11 C.P. 83000 MEXICO

$12{ }^{4}$ Departamento de Geoquimica, Instituto de Geologia, Universidad Nacional Autonoma de

13 Mexico (UNAM), Mexico D.F., C.P. 04510, MEXICO

$14{ }^{5}$ Herbario USON, Departamento de Investigaciones Cientificas y Tecnologicas, Universidad de

15 Sonora, Niños Heroes entre Rosales y Pino Suarez, Hermosillo, Sonora C.P. 83000, MEXICO

$16{ }^{6}$ Department of Soil, Water and Environmental Science, University of Arizona, Tucson, Arizona

17 85721-0038, USA.

$18{ }^{7}$ Laboratorio Nacional de Ciencias de la Sostenibilidad, Instituto de Ecologia, Universidad

19 Nacional Autonoma de Mexico, Apartado Postal 70-275, Mexico D.F., C.P. 04510, MEXICO 
$20{ }^{8}$ Current address: Instituto de Geologia, Universidad Nacional Autonoma de Mexico, Estacion

21 Regional del Noroeste, Avenida Luis Donaldo Colosio s/n esquina Madrid, Apartado Postal

22 1039, Hermosillo, Sonora C.P. 83000 MEXICO.

23

$24 \quad{ }^{9}$ Author for correspondence: freaner@unam.mx

25

26 Running head: Plants from the Nacozari mine tailings.

27

28

29

30

31

32

33

34

35 


\section{ABSTRACT}

Phytostabilization is a remediation technology that uses plants for $i n-s i t u$ stabilization of contamination in soils and mine tailings. The objective of this study was to identify native plant species with potential for phytostabilization of the abandoned mine tailings in Nacozari, Sonora in northern Mexico. A flora of 42 species in 16 families of angiosperms was recorded on the tailings site and the abundance of the most common perennial species was estimated. Four of the five abundant perennial species showed evidence of regeneration: the ability to reproduce and establish new seedlings. A comparison of selected physicochemical properties of the tailings in vegetated patches with adjacent barren areas suggests that $\mathrm{pH}$, electrical conductivity, texture, and concentration of potentially toxic elements do not limit plant distribution. For the most abundant species, the accumulation factor for most metals was $<1$, with the exception of $\mathrm{Zn}$ in two species. A short-term experiment on adaptation revealed limited evidence for the formation of local ecotypes in Prosopis velutina and Amaranthus watsonii. Overall, the results of this study indicate that five native plant species might have potential for phytostabilization of the Nacozari tailings and that seed could be collected locally to revegetate the site. More broadly, this study provides a methodology that can be used to identify native plants and evaluate their phytostabilization potential for similar mine tailings. 
Unreclaimed mine tailings represent an important environmental problem as aeolian dispersion and water erosion may transfer potentially toxic elements into local trophic webs and nearby human settlements (Mendez \& Maier, 2008). Phytostabilization is a form of remediation that involves the use of plants for in-situ stabilization of tailings and contaminants (Mendez \& Maier, 2008). Implementing phytostabilization in a particular tailing requires identification of suitable plant species for specific ecological conditions as well as the appropriate amendments to allow plant germination and growth. In arid and semiarid environments, plants suitable for phytostabilization should be native, drought-, salt- and metal-tolerant and should limit shoot metal accumulation (Mendez \& Maier, 2008). However, in highly modified novel ecosystems (sensu Hobbs, Higgs \& Harris 2009), non-native species could be considered if they are not

71 invasive and provide desirable levels of phytostabilization.

73 Surveys of native plants that naturally colonize mine tailings offer the opportunity to identify

74 species with potential in phytostabilization (Carrillo-Gonzalez \& Gonzalez-Chavez, 2006;

75 Cortes-Jimenez et al., 2013). Using native species has several advantages including adaptation to

76 local environmental conditions and avoiding the introduction of invasive species that may affect

77 local plant communities. Analysis of the pattern of metal accumulation among plants growing spontaneously in mine tailings allows identification of species with the best potential for phytostabilization (Santos-Jallath et al., 2012; Cortes-Jimenez et al., 2013). If bioconcentration 
80 (total element concentration in shoot tissue $\div$ total element concentration in mine tailings) or

81 accumulation factors are greater than 1, species are not suitable for phytostabilization but may

82 have potential for phytoextraction; in contrast, if these ratios are less than one and if metal

83 concentrations in plant tissues do not reach animal toxicity levels, species have potential for

84 phytostabilization (Mendez \& Maier, 2008).

85

86 Studies on the relationships between plant abundance and the physicochemical properties of

87 mine waste have identified some of the factors that limit plant establishment in mine tailings

88 (Conesa, Faz \& Arnaldos, 2006; Anawar et al., 2013; Parraga-Aguado et al., 2013). Some of the

89 tailing properties that have been found to influence plant abundance and distribution include $\mathrm{pH}$

90 (Conesa, Faz \& Arnaldos, 2006), salinity (Parraga-Aguado et al., 2013) and metal concentration

91 (Ortiz-Calderon, Alcaide \& Li-Kao, 2008) and bioavailability (Kidd et al., 2007; Perlatti et al.,

92 2016). Identifying the physicochemical properties of tailings that restrict plant establishment may

93 be critical for the implementation of phytostabilization and for understanding the type of

94 amendments needed (i.e. compost-assisted) to facilitate seedling establishment (Parraga-Aguado

95 et al., 2013; Gil-Loaiza et al., 2016).

97 Studies of plant adaptation to local mine wastes where metals are bioavailable have important

98 implications for the implementation of phytostabilization. The mechanism involved in the

99 evolution of metal tolerance has been documented in many plant species (Antonovics, Bradshaw

$100 \&$ Turner, 1971; Baker, 1987). Metal tolerant populations evolve through natural selection in

101 response to high levels of metals in mine wastes (Ke et al., 2007). If metal tolerant ecotypes have 
102 evolved locally, phytostabilization should take advantage of such local ecotypes as they provide

103 better cover and persistence than commercial varieties when grown on mine wastes (Smith \&

104 Bradshaw, 1979). Thus, the implementation of phytostabilization should take into account

105 whether local plant ecotypes have evolved in particular mine tailings.

107 Past and current mining activities in northern Mexico have generated large amounts of unconfined mine wastes that poses risks to human populations and adjacent ecosystems (Jimenez et al., 2006). The Nacozari region in northeastern Sonora, hosts important copper deposits and one of the most important copper mines in northwestern Mexico. The Moctezuma Copper

111 Company operated the Pilares mine east of Nacozari from 1900 to 1949 and generated several

112 million tons of waste distributed in three tailings deposits that cover 52 ha around the town

113 (Alvarado \& Volke, 2004; De la O Villanueva et al., 2013). Selected physicochemical

114 parameters from these tailings have been described, including mineral composition (Romero et

115 al., 2008), texture (De la O Villanueva et al., 2013), pH, electrical conductivity and metal content

116 (Meza-Figueroa et al., 2009). Although metal concentration in tailings is relatively low, the

117 seasonal formation of efflorescent salts represents a serious problem; these salts can have high

118 metal concentrations and are subject to wind dispersion which can move toxic metals from the 119 tailings into nearby residential soils (Meza-Figueroa et al., 2009). Meza-Figueroa et al. (2009) 120 suggest that one alternative for prevention of off-site aeolian dispersion and water erosion of the 121 tailings is to create a vegetative cap using native plants. However, knowledge of the native plants 122 growing near or on the Nacozari tailings and their potential in phytostabilization is limited. 
124 Native plants have colonized the Nacozari tailings, although the distribution is localized and

125 patchy and is not sufficient to prevent aeolian dispersion or water erosion. The overall goal of

126 this study is to identify plant species with potential for phytostabilization of this site. Our

127 objectives are to: a) describe the taxonomic composition of the plant species growing in the

128 Nacozari tailings; b) describe the abundance and population structure of the most common

129 species; c) explore the physicochemical parameters that may limit plant distribution; d) describe

130 the pattern of metal accumulation in the most common plant species and e) evaluate through

131 short-term experiments whether local ecotypes have evolved in two of the plant species.

\section{MATERIAL AND METHODS}

Study area. -The Nacozari mining district is located in northeastern Sonora, $123 \mathrm{~km}$ south of the Arizona (USA) border. The regional climate is semi-arid (BS1) with the mean temperature in Nacozari ranging from $12.1^{\circ} \mathrm{C}$ during January to $27.9^{\circ} \mathrm{C}$ during June. Mean annual rainfall is 578 $\mathrm{mm}$ with more than $60 \%$ occurring during July, August and September (Servicio Meteorologico Nacional, 2015). Regional vegetation is foothills thornscrub at lower elevations and oak woodland at higher elevations (Martinez-Yrizar, Felger \& Burquez, 2010). Around Nacozari, common species from the thornscrub vegetation include Acacia constricta, Acacia farnesiana, Fouquieria splendens, Stenocereus thurberi and Mimosa dysocarpa. Along the Nacozari River, common species of the riparian vegetation include Prosopis velutina, Parkinsonia aculeata, Baccharis sarothroides, Baccharis salicifolia and Acacia farnesiana. According to the Nacozari 144 soil chart H12-6 (INEGI 2006), local soils include Leptosols, Phaeozems and Regosols. Meza145 Figueroa et al. (2009) described some properties of the background soils north of Nacozari. Cu 
146 contents from background soils ranged from 48 to $96 \mathrm{mg} / \mathrm{kg}$, whereas residential soils contained

147 higher $\mathrm{Cu}$-values of $200 \mathrm{mg} / \mathrm{kg}$ due to proximity of tailings.

149 The mining district hosts important ore deposits, including porphyry copper, breccia pipe and

150 veins with $\mathrm{Cu}, \mathrm{Mo}, \mathrm{Au}, \mathrm{Ag}$ and $\mathrm{Zn}$ (Alvarado \& Volke, 2004). The Pilares copper ore deposit

$151(0.7-1.2 \% \mathrm{Cu})$ was discovered in 1886 and purchased years later by the Moctezuma Copper

152 Company (Phelps Dodge subsidiary). Mining activity lasted around 50 years, producing around

1533000 ton/day of copper until the mine was closed in 1949. Large amounts of waste were

154 distributed into three deposits around the town of Nacozari and then abandoned (Alvarado \&

155 Volke, 2004).

157 The three tailing deposits differ in size: 1) the central tailings deposit is medium-sized and

158 located within the urban area, at the southern margin of town, 2) the southern deposit is the 159 smallest and is located just south of Nacozari along the Moctezuma-Agua Prieta road, and 3) the 160 southeastern deposit is the largest and is located along the Nacozari-La Caridad road (Alvarado

$161 \&$ Volke, 2004). Although the three deposits have been studied (Alvarado \& Volke, 2004), work

162 has concentrated on the central tailings deposit because of its proximity to the town (Meza-

163 Figueroa et al., 2009). The mineral composition of this deposit is mainly quartz $\left(\mathrm{SiO}_{2}\right)$, gypsum

$164\left(\mathrm{CaSO}_{4} \cdot 2 \mathrm{H}_{2} \mathrm{O}\right)$, lepidocrocite $(\mathrm{YFeO}[\mathrm{OH}])$ and copper sulfate $\left(\mathrm{CuSO}_{4}\right.$, Romero et al., 2008).

165 Mean $\mathrm{pH}$ is $3.8 \pm 0.3$ and mean electrical conductivity is $340.1 \pm 2 \mu \mathrm{S} / \mathrm{cm}$ (Meza-Figueroa et al.,

166 2009). Texture analysis revealed that $80 \%$ of the material is coarse grained with significant

167 variation in particle size from coarse sand to fine silt (De la O-Villanueva et al., 2013). The most 
168 common metals in the center deposit are Fe $(31,739 \pm 381.9 \mathrm{mg} / \mathrm{kg}), \mathrm{Cu}(400.5 \pm 15.8 \mathrm{mg} / \mathrm{kg})$,

$169 \mathrm{Rb}(298.4 \pm 5.6)$ and $\mathrm{Mn}(158.5 \pm 10.5 \mathrm{mg} / \mathrm{kg})$; mean values of $\mathrm{As}$ and $\mathrm{Pb}$ are $29.3 \pm 4$ and $39 \pm$

$1704.2 \mathrm{mg} / \mathrm{kg}$ respectively (Meza-Figueroa et al., 2009). However, some metals including $\mathrm{Cu}, \mathrm{Mn}$,

$171 \mathrm{Zn}$ and $\mathrm{Ba}$, reach very high values in efflorescent salts (e.g., $\mathrm{Cu}: 68,751 \pm 865 \mathrm{mg} / \mathrm{kg}$ ), and are

172 highly susceptible to aeolian transport into nearby residential soils (Meza-Figueroa et al., 2009).

174 This study focused on the central deposit which has an area of approximately 19 ha, a volume of

1751.5 million $\mathrm{m}^{3}$ and a mass of 3.3 million tons (De la O-Villanueva et al., 2013). This tailing is

176 located at $30^{\circ} 22^{\prime} 2.4^{\prime \prime} \mathrm{N}$ and $109^{\circ} 41^{\prime} 38^{\prime \prime} \mathrm{W}$ at an elevation of 1050 masl. The entire deposit

177 was explored for perennial plants resulting in the identification of just four patches that contained

178 all plants. Patch size varied from 34 to $743 \mathrm{~m}^{2}$ for a total of $1591 \mathrm{~m}^{2}$ or $0.84 \%$ of the total area of

179 the deposit.

Plant inventory. - The tailings were visited six times during the year in order to collect

182 specimens of perennial species from each of the four patches during the flowering season.

183 Annual species were collected during the summer rainy season. Species were identified using

184 local floras (i.e. for trees: Felger, Johnson \& Wilson, 2001) or by comparison with specimens

185 deposited at the University of Sonora Herbarium. Collection was made under Scientific License

186

FLOR-0090 by SEMARNAT.

187

Abundance and population structure. - The abundance of perennial species was determined 
190 size, we used as many contiguous plots as necessary in order to cover the entire area of each

191 patch and obtain a census of all perennial plants growing in the tailings. Within each plot the

192 identity of each individual was recorded and its height was measured with a metric tape for

193 shrubs and a graduated telescoping pole for trees. For annual species, a $1 \mathrm{~m}^{2}$ sampling plot was

194 used randomly distributed within each patch. We used a total of $6\left(1 \mathrm{~m}^{2}\right)$ plots per patch. For this

195 set of plants only the identity of each individual and the number of plants per plot were recorded.

Relation between plant distribution and physicochemical properties of tailings. - We compared

several physicochemical properties of tailings in patches with vegetation and in areas without

vegetation. We used a paired sampling approach taking tailings samples $(0-20 \mathrm{~cm}$ in depth) from

each patch with perennial plants and adjacent areas with no vegetation. For each pair we took 3

randomly located samples that were combined to form a composite sample $(1 \mathrm{~kg})$; in total we

obtained four composite samples from plant patches and four composite samples from areas

without vegetation $(n=8)$. Once in the lab, samples were dried and homogeneized. The $\mathrm{pH}$ and

electrical conductivity (EC) were determined in solid suspensions (1:20 solid:water) using a 100

Ecosense $\mathrm{pH}$ meter and a portable conductivity meter (Hanna), respectively. Particle size

For metal analysis, homogenized tailing samples were placed in plastic bags and measured 
212 and performance checks of PXRF analysis. Values for elements that fell within the $\pm 20 \%$ values

213 of the standard were taken as accurate.

Patterns of metal accumulation in plants. - The perennial species abundance survey was used to

216 select the five most abundant species for analysis of metal accumulation. Tailing samples (200 g)

217 were collected from the rhizosphere and 5-10 leaves were randomly collected from 6 individuals

218 of each species distributed in at least two patches. Leaf tissue was rinsed with distilled water

219 several times in the field and transported to the lab. Once in the lab, leaf tissue was rinsed with

220 deionized water and dried at $50^{\circ} \mathrm{C}$ for $48 \mathrm{~h}$. Dried leaf tissues were ground in an agate mortar for

221 analysis of metals. Metals in tailing material from the rhizosphere and from leaves were analyzed

222 as previously described (PXRF).

Experiment on local adaptation in an annual and a perennial species. - In order to test whether a Amaranthus watsonii (annual) were collected from individual plants (four $P$. velutina trees and ten A. watsonii plants) growing within the tailings deposit and growing in an off-site area close each of the sites where seeds were collected. These samples (tailings and off-site soil) were used and the other half with off-site soil. Each family (seeds derived from a single plant) from each 
234 site was grown in both tailings and off-site soil. Tubes received either five $A$. watsonii seeds or

235 one $P$. velutina seed. Seven tubes per mother (family) for a total of 140 tubes were used for $A$.

236 watsonii, whereas for $P$. velutina, from 7 to 40 tubes per mother for a total of 226 tubes were

237 used. Tubes were regularly irrigated and the experiment lasted one month. The following

238 parameters were recorded: emergence, height, number of leaves and total, root, shoot and leaf 239 dry mass after $30 \mathrm{~d}$ after germination.

241 Statistical analysis. - Plant abundance is expressed as boxplots describing variation of the

242 number of perennial and annual individuals recorded across plots among the four patches.

243 Histograms with the frequencies of different size (height) classes found for each species were

244 used to describe the population structure and the pattern of regeneration of the most abundant

245 perennial species (Silvertown \& Charlesworth, 2007). Measured parameters including pH, EC,

246 texture (sand frequency), and metal concentrations in patches with vegetation and areas without

247 vegetation were compared using paired t-tests. We employed the Bonferroni correction for

248 multiple testing using R (R Core Team 2013). Ratios of metal accumulation were calculated

249 from the mean values found for individuals (leaves/rhizosphere) of all species. A $\chi^{2}$ test was used

250 to determine whether the ratios were significantly greater than 1. For local adaptation, a two-way

251 ANOVA was used to evaluate whether there were significant differences in height, number of

252 leaves and total dry mass due to origin of plants (tailing $v s$. soil), growth media (tailing $v s$. soil)

253 and their interaction. We used Tukey HSD as post hoc analysis to evaluate differences between

254 treatments. Local adaptation is inferred if the results show that plants collected from tailings

255 grew better in tailings than in off-site soil and if plants collected from off-site grew better in off- 
256 site soil than in tailings. All statistical analyses, except the Bonferroni correction, were

257 performed with JMP (SAS Institute, 1997).

\section{RESULTS}

Plant inventory. - We recorded a total of 42 species of plants distributed in 16 families of angiosperms (Appendix 1). The most common families were Poaceae and Asteraceae.

Abundance and population structure. - A total of 872 individuals of perennial species were recorded growing in four patches in the central tailing. The five most common perennial species were, in order of decreasing abundance: Acacia farnesiana $(\mathrm{N}=540)$, Brickellia coulteri ( $\mathrm{N}=126)$, Gnaphalium leucocephalum $(\mathrm{N}=108)$, Baccharis sarothroides $(\mathrm{N}=81)$ and Prosopis velutina $(\mathrm{N}=17)$. The abundance (number of individuals $/ 100 \mathrm{~m}^{2}$ ) varied among patches with mean values between 0 and 13 individuals/100 $\mathrm{m}^{2}$ (Fig 1). Among the perennial species, three patterns of population structure were observed: a) species that are actively regenerating with a large number of the small size classes (seedlings) like $A$. farnesiana (Fig 2); b) species with large number of intermediate size classes (juvenile and adults), like B. coulteri, B. sarothroides and $G$.

272 leucocephalum that are still regenerating (Fig 2) and c) species with no evidence of recent 273 regeneration like $P$. velutina and composed mainly of large size (adults) classes (Fig 2).

274 The most common annual species were Amaranthus watsonii, Boerhavia coulteri, Solanum holtzianum and Bromus catharticus (Fig 1). The abundance varied among patches with mean

276 values between 0 and 16 individuals $/ \mathrm{m}^{2}$. 
Relation between plant distribution and physicochemical properties of tailings. - There were no significant differences for most measured physicochemical properties between samples taken from patches with vegetation and adjacent areas with no vegetation $(\mathrm{pH}, \mathrm{EC}$, texture, and metal content) (Table 1). The correction for multiple testing revealed the same result: there were no significant differences between samples from vegetation patches and barren patches (Table 1).

Patterns of metal accumulation in plants. - The accumulation factor (leaf/rhizosphere) for most metals in the five most abundant plant species was below 1 (Table 2). The exceptions were for

$\mathrm{Zn}$ in B. sarothroides and G. leucocephalum where ratios of the accumulation factors were species reached the domestic animal toxicity limit $(15 \mathrm{mg} / \mathrm{kg}$ for sheep and $40 \mathrm{mg} / \mathrm{kg}$ for cattle;

Natural Research Council, 2005). Similarly, for Mo all plant species also reached the toxicity limit of the maximum tolerable range as $\mathrm{Zn}$ for $G$. leucocephalum and $\mathrm{Ca}$ for $P$. velutina (Appendix 2).

Experiment on local adaptation in an annual and a perennial species. -

For A. watsonii, seedling emergence varied between $30 \%$ and $44 \%$ among treatments. After emergence, seedling survival varied between $83 \%$ and $90 \%$ among treatments. Seedlings growing in tailing material reached $2.8 \pm 0.4$ to $3.1 \pm 0.5$ (mean \pm standard deviation) $\mathrm{cm}$ in 
299 height after $30 \mathrm{~d}$ whereas seedlings growing in off-site soil reached $7.4 \pm 1.3$ to $8.2 \pm 0.9 \mathrm{~cm}$ (Fig

$3003 \mathrm{~A})$. The statistical analysis revealed a significant difference due to growth medium $(\mathrm{F}=426.64, \mathrm{p}$

$301<0.001, \mathrm{df}=1 / 208)$, no significant difference due to seed origin $(\mathrm{F}=0.71, \mathrm{p}=0.398, \mathrm{df}=1 / 208)$

302 and a significant interaction $(\mathrm{F}=7.39, \mathrm{p}=0.007, \mathrm{df}=1)$. However, the Tukey test revealed

303 significant differences in height only between substrates and not between sites of seed origin (Fig

$3043 \mathrm{~A})$. The mean number of leaves from seedlings growing in tailing material was 2 whereas

305 seedlings growing in soil had 7 leaves (Fig 3B). As for growth, the statistical analysis indicates a

306 significant difference due to growth medium $(\mathrm{F}=391.41, \mathrm{p}<0.001, \mathrm{df}=1 / 208)$, no significant

307 difference due to seed origin $(\mathrm{F}=0.01, \mathrm{p}=0.916, \mathrm{df}=1 / 208)$ and no significant interaction

$308(\mathrm{~F}=0.52, \mathrm{p}=0.469, \mathrm{df}=1)$. The Tukey test revealed significant differences in number of leaves

309 only between substrates and not between sites of seed origin (Fig 3B). For total dry mass,

310 seedlings growing in tailing material accumulated $0.005 \pm 0.003$ to $0.007 \pm 0.004 \mathrm{~g}$ and

311 seedlings growing in soil accumulated $0.06 \pm 0.01$ to $0.08 \pm 0.02 \mathrm{~g}$ (Fig 3C). In this case, the

312 analysis shows significant differences due to the growth medium $(F=250.54, p<0.001$,

$313 \mathrm{df}=1 / 208)$, seed origin $(\mathrm{F}=8.01, \mathrm{p}=0.005, \mathrm{df}=1 / 208)$ and the interaction was significant

$314(\mathrm{~F}=11.96, \mathrm{p}=0.001, \mathrm{df}=1)$. In this case, the Tukey test revealed that seedlings derived from off-

315 site soil and grown in soil accumulated greater biomass than seedlings derived from tailings

316 growing in soil (Fig 3C).

318 For P. velutina, seedling emergence ranged from $67 \%$ to $98 \%$ among treatments. After

emergence, seedling survival varied between $57 \%$ to $88 \%$ among treatments. After $30 \mathrm{~d}$ growth,

321 growing in off-site soil reached $8.8 \pm 0.3$ to $9 \pm 0.6 \mathrm{~cm}$ (Fig 3D). The statistical analysis indicates 
322 a significant difference due to growth medium $(\mathrm{F}=475.38, \mathrm{p}<0.001, \mathrm{df}=1 / 317)$, no significant

323 difference due to seed origin $(\mathrm{F}=0.10, \mathrm{p}=0.749, \mathrm{df}=1 / 317)$ and no significant interaction $(\mathrm{F}=0.32$,

$324 \mathrm{p}=0.569, \mathrm{df}=1)$. The Tukey test revealed significant differences in height only between substrates

325 and not between sites of seed origin (Fig 3D). For the number of leaves, seedlings growing in

326 tailing material had $3.1 \pm 0.9$ to $3.7 \pm 0.7$ leaves whereas seedlings growing in off-site soil had

$3274.6 \pm 1.7$ to $7.5 \pm 1.6$ (Fig 3E). In this case, a significant difference was detected due to growth

328 medium $(\mathrm{F}=91.86, \mathrm{p}<0.001, \mathrm{df}=1 / 317)$, seed origin $(\mathrm{F}=33.84, \mathrm{p}<0.001, \mathrm{df}=1 / 317)$ and a

329 significant interaction $(\mathrm{F}=25.19, \mathrm{p}<0.001, \mathrm{df}=1)$. In this case, the Tukey test revealed significant

330 greater number of leaves in seedlings derived from off-site soil growing in soil than seedlings

331 derived from tailings growing in soil (Fig 3E). For total dry mass, seedlings growing in tailings

332 accumulated $0.019 \pm 0.009$ to $0.02 \pm 0.003 \mathrm{~g}$ whereas seedlings growing in off-site soil

333 accumulated $0.06 \pm 0.01$ to $0.07 \pm 0.02 \mathrm{~g}$ (Fig 3F). As for number of leaves, a significant

334 difference in dry mass was detected due to growth medium $(\mathrm{F}=192.46, \mathrm{p}<0.001, \mathrm{df}=1 / 317)$, due

335 to seed origin $(\mathrm{F}=15.15, \mathrm{p}<0.001, \mathrm{df}=1 / 317)$ and a significant interaction $(\mathrm{F}=10.51, \mathrm{p}=0.001$,

$336 \mathrm{df}=1$ ). The Tukey test revealed significant greater biomass in seedlings derived from off-site soil

337 growing in soil than seedlings derived from tailings growing in soil (Fig 3F).

\section{DISCUSSION}

339 Successful implementation of phytostabilization on mine tailings, the establishment of a

340 permanent vegetative cover, requires careful consideration of the plants to be used. This ideally

341 includes a combination of different perennial species with different rooting depths and canopy

342 cover structure that do not accumulate metals into shoot tissues (Mendez \& Maier, 2008). In

343 addition, the geographic range of plant species must be taken in consideration, making plants that

344 can naturally colonize mine tailings of interest for their phytostabilization potential. This study 
345 identified 42 different species of plants growing in small patches on the abandoned Nacozari

346 mine tailings. Fifteen of these species were perennial whereas twenty seven were annual. From

347 the set of fifteen perennial species, only five were abundant and from this set, four of the five

348 showed clear evidence of regeneration, i.e., the ability to reproduce and establish new seedlings.

349 This set of perennial species normally produces seeds almost every year (Molina-Freaner, pers.

350 obs.) but recent seedling establishment is restricted to A. farnesiana, B. coulteri, $B$. sarothroides

351 and G. leucocephalum. We do not know the mechanism that restricts recent seedling

352 establishment in P. velutina and future studies should identify the regeneration barriers of

353 perennial species in this tailings. Taken together, these results suggest that this set of species has

354 potential for phytostabilization of the Nacozari tailings, as they include trees (P. velutina and $A$.

355 farnesiana) with relatively large canopy cover and deep roots, and shrubs (B. coulteri, $B$.

356 sarothroides and G. leucocephalum) with smaller cover and relatively shallower roots (Molina-

357 Freaner, pers. obs).

359 Annual species identified on this site had greater diversity (27/42) than the perennial species

360 (15/42). However, annual species have a more limited potential for phytostabilization given their

361 shallow roots, short life cycles and the fact that they grow only during the summer rainy season

362 in this region (Shreve \& Wiggins, 1964). However, they may regularly add organic matter to the

363 tailings facilitating the establishment of perennial species and reducing erosion.

365 Identifying factors that limit plant establishment in tailings is an important goal in

366 phytostabilization (Parrado-Aguado et al., 2013). This study recorded only four patches of 
367 vegetation on the tailings, representing $0.84 \%$ of the 19 ha surface area. These patches which

368 contained 872 individuals of perennial species have very slowly colonized the tailings over more

369 than 6 decades since the mine was closed in 1949. This suggests there are key inhibitory factors

370 preventing seed germination and seedling establishment at this site. Paired sampling comparing

371 patches of vegetation with adjacent barren areas revealed no differences in $\mathrm{pH}$, electrical

372 conductivity, texture or the concentration of potentially toxic elements. So, these factors do not

373 influence the distribution of plants in the four patches at this site. Future studies should explore

374 whether organic matter, major nutrients (such as $\mathrm{N}$ or P), metal bioavailability, moisture content,

375 or the composition of microbial communities restrict plant establishment in this site to these four 376 small patches.

378 Plants used in phytostabilization should be metal tolerant but limit metal accumulation into 379 above ground tissues in order to avoid transferring toxic elements into food chains (Mendez \& 380 Maier, 2008). The five most abundant plant species from the Nacozari tailings had metal 381 accumulation ratios that were generally below 1 . The exception was $\mathrm{Zn}$ for which two perennial 382 species had accumulation factors greater than 1. Thus, of the five most abundant perennial 383 species, three comply with the requirement of low accumulation. In addition, plants suitable for phytostabilization should have metal concentration in their leaves below the maximum tolerable level for animals (Mendez \& Maier, 2008). In our study, we recorded that the five most abundant perennial species have $\mathrm{Cu}$ and Mo concentration in their leaves above animal toxicity levels

387 (Natural Research Council, 2005). Given the accumulation of $\mathrm{Cu}, \mathrm{Mo}$ and $\mathrm{Zn}$ in the most 388 abundant species, future studies should explore whether amendments such as compost, could reduce metal accumulation and meet requirements for animal toxicity (Solis-Dominguez et al., 
390 2012). It is important to note that plant metal uptake into above ground shoot tissue is not

391 necessarily related to the total amount of metals in tailings; rather, it is related to the bioavailable

392 metal concentration in the tailings (Perlatti et al., 2015) and also to the efficiency of the metal

393 transport system in each plant (Verkleji et al., 2009). Thus, both mine tailings and plant species

394 characteristics ultimately influence plant metal uptake and will have to be evaluated on a site-

395 specific basis when using phytostabilization technology.

397 The success of phytostabilization depends on the use of locally adapted plants. It has been

398 previously suggested that using locally adapted ecotypes provides better cover and persistence

399 than other sources of seeds when grown in mine wastes (Smith \& Bradshaw, 1979). Our short-

400 term experiments testing local adaptation in an annual and a perennial species did not detect

401 strong evidence of tailings ecotypes even after a period of more than 60 years. Our data reveal

402 that tailings as a growth substrate significantly reduced the amount of biomass produced when

403 compared with plants grown in off-site soil. The effect of seed origin was contingent upon

404 substrate, as seedling derived from plants growing in off-site soil had equal or greater

405 performance than those derived from tailings plants when grown in soil. However, there were no

406 significant differences due to seed origin when grown in tailings substrate. We suggest that

407 differences in the maternal environment associated with abiotic stress (metals in tailings) might

408 have an effect on progeny performance in seedlings coming from tailings. Similar patterns have

409 been observed in other species (Sultan et al. 2009; Zas et al. 2013). However, both the annual

410 and perennial species tested show that seeds harvested from plants growing on the tailings site or

411 in a neighboring off-site area are equally effective for phytostabilization in the Nacozari tailings. 
412 Thus, we suggest that future field studies in the Nacozari tailings should use regionally-adapted

413 sources of seeds.

414

415 In conclusion, this plant inventory identified several native perennial species with potential for

416 phytostabilization of the Nacozari mine tailings. One advantage of using these plants is that seed

417 could be collected locally and used to revegetate the site. However, two of the species identified

418 accumulate $\mathrm{Zn}$ and all species accumulate $\mathrm{Cu}$ and $\mathrm{Mo}$ into the range of maximum tolerable

419 levels for animals (National Research Council, 2005). Thus, measures should be taken to

420 evaluate and minimize the risk of transferring toxic elements into the local food chain.

421

422 Acknowledgements: We thank Jose Martinez for field and lab assistance.

423

424

425

426

427

428

429

430

431 
432 REFERENCES

433 Alvarado VJ, Volke TL. 2004. Informe de resultados del proyecto, metodo de analisis y

434 propuesta para el manejo de los residuos mineros del sitio de Nacozari, Sonora.

435 SEMARNAT-INE, Mexico D.F. Available at:

436

www.inecc.gob.mx/descargas/dgcenica/nacozari 2004.pdf

437

438

439

440

441

442

443

444

445

446

447

448

449

450

451

452

Anawar HM, Canha N, Santa-Regina I, Freitas MC. 2013. Adaptation, tolerance, and evolution of plant species in a pyrite mine in response to contamination level and properties of mine tailings: sustainable rehabilitation. Journal of Soil Sediments 13: 730-741.

DOI:10.1007/s11368-012-0641-7

Antonovics J, Bradshaw AD, Turner RG. 1971. Heavy metal tolerance in plants. Advances in Ecological Research 7: 1-85. doi:10.1016/S0065-2504(08)60202-0

Baker AJM. 1987. Metal tolerance. New Phytologist 106: 93-111. DOI: 10.1111/j.14698137.1987.tb04685.x

Beare HB, Bruce RR.1993. A comparison of methods for measuring water-stable aggregates: implications for determining environmental effects on soil structure. Geoderma 56: 87104. doi:10.1016/0016-7061(93)90102-Q 
454 Carrillo-Gonzalez R, Gonzalez-Chavez MCA. 2006. Metal accumulation in wild plants

455 surrounding mining wastes. Environmental Pollution 144: 84-92.

456 doi:10.1016/j.envpol.2006.01.006

457

458 Conesa HM, Faz A, Arnaldos R. 2006. Heavy metal accumulation and tolerance in plants from

459

460

461

462

463

464

465

466

467

468

469

470

471

472

473 mine tailings of the semi-arid Cartagena-La Union mining district (SE Spain). Science of the Total Environment 366: 1-11. doi:10.1016/j.scitotenv.2005.12.008

Cortes-Jimenez EV, Mugica-Alvarez V, Gonzalez-Chavez MCA, Carrillo-Gonzalez R, Martinez-Gordillo M, Vaca-Mier M. 2013. Natural revegetation of alkaline tailing heaps at Taxco, Gerrero, Mexico. International Journal of Phytoremediation. 15: 127-141. DOI:10.1080/15226514.2012.683208

De la O-Villanueva M, Meza-Figueroa D, Maier RM, Moreno D, Gomez-Alvarez A, Del RioSalas R, Mendivil H, Montijo A. 2013. Procesos erosivos en jales de la presa I de Nacozari de Garcia, Sonora y su efecto en la dispersión de contaminantes. Boletin de la Sociedad Geologica Mexicana 65: 27-38.

Felger RS, Johnson MB, Wilson MF. 2001. The Trees of Sonora, Mexico. Oxford University Press, Oxford. 
475 Gil-Loaiza J, White SA, Root RA, Solis-Dominguez FA, Chorover J, Maier RM. 2016.

476 Phytostabilization of mine tailings using compost-assisted direct planting: translating 477 greenhouse results to the field. Science of the Total Environment 565:451-461.

478 doi:10.1016/j.scitotenv.2016.04.168

479

480 Gomez-Bernal J M, Santana-Carrillo J, Romero-Martín F, Armienta-Hernandez MA, MortonBermea O, Ruiz-Huerta EA. 2010. Plantas de sitios contaminados con desechos mineros

482 en Taxco, Guerrero, México. Boletín de la Sociedad Botánica de México 87:131-133.

Hobbs R J, Higgs E, Harris J A. 2009. Novel ecosystems: implications for conservation and restoration. Trends in Ecology and Evolution 24: 599-605. doi:10.1016/j.tree.2009.05.012

486

487

INEGI. 2006. www.inegi.org.mx/geo/contenidos/recnat/edafologia Accesed december 2016

Jimenez C, Huante P, Rincon E. 2006. Restauracion de minas superficiales en Mexico.

490 SEMARNAT, Mexico D.F. 83 p. Available at:

491 biblioteca.semarnat.gob.mx/janium/Documentos/Ciga/Libros2011/CG006488.pdf 
493 Ke W, Xiong ZT, Chen S, Chen J.2007. Effects of copper and mineral nutrition on growth,

494

495

496

497

498

499

500

501

502

503

504

505

506

507

508

509

510

511

512 Meza-Figueroa D, Maier RM, de la O-Villanueva M, Gomez-Alvarez A, Moreno-Zazueta A, 513 copper accumulation and mineral element uptake in two Rumex japonicus populations from a copper mine and an uncontaminated field site. Environmental and Experimental Botany 59: 59-67. doi:10.1016/j.envexpbot.2005.10.007

Kidd, P S, Dominguez-Rodriguez M J, Diez J, Monterroso C. 2007. Bioavailability and plant accumulation of heavy metals and phosphorus in agricultural soils amended by long-term application of sewage sludge. Chemosphere 66:1458-1467. doi.org/10.1016/j.chemosphere.2006.09.007

Martínez-Yrizar A, Felger RS, Burquez A. 2010. Los ecosistemas terrestres: un diverso capital natural. In: Diversidad biologica de Sonora, Eds: Molina-Freaner FE, TR Van-Devender. CONABIO-UNAM, Mexico. Pp. 129-156.

Mendez MO, Maier RM. 2008. Phytostabilization of mine tailings in arid and semi-arid environments - An emerging remediation technology. Environmental Health Perspectives 116: 278-283. doi: 10.1289/ehp.10608 Rivera J, Campillo A, Grandlic CJ, Anaya R, Palafox-Reyes J. 2009. The impact of 
514

515

516

517

518

519

520

521

522

523

524

525

526

527

528

529

530

531

532

533

534 unconfined mine tailings in residential areas from a mining town in a semi-arid environment: Nacozari, Sonora, Mexico. Chemosphere 77: 140-147.

doi:10.1016/j.chemosphere.2009.04.068

Natural Research Council. 2005. Mineral tolerance of animals. $2^{\text {nd }}$ ed. The National Academies Press, Washington.

Ortiz-Calderon C, Alcaide O, Li-Kao J. 2008. Copper distribution in leaves and roots of plants growing on a copper mine tailing storage facility in northern Chile. Revista Chilena de Historia Natural 81: 489-499. http://dx.doi.org/10.4067/S0716-078X2008000400004

Parraga-Aguado I, Gonzalez-Alcaraz MN, Alvarez-Rogel J, Jimenez-Carceles FJ, Conesa HM. 2013. The importance of edaphic niches and pioneer plant species succession for the phytomanagementof mine tailings. Environmental Pollution 176: 134-143. doi:10.1016/j.envpol.2013.01.023

Perlatti, F., T.O. Ferreira, R.E. Romero, M.C.G. Costa, X.L. Otero. 2015. Copper accumulation and changes in soil physical-chemical properties promoted by native plants in an abandoned mine site in northeastern Brazil: Implications for restoration of mine sites. Ecological Engineering 82:103-111. doi.org/10.1016/j.ecoleng.2015.04.085 
536 Romero FM, Armienta MA, Gutierrez ME, Villaseñor G. 2008. Factores geologicos y climaticos 537 que determinan la peligrosidad y el impacto ambiental de jales mineros. Revista Internacional de Contaminacion Ambiental 24: 43-54.

539

540

541

Santos-Jallath J, Castro-Rodriguez A, Hueso-Casillas J, Torres-Bustillos L. 2012. Arsenic and 541 heavy metals in native plants at tailings impoundments in Queretato, Mexico. Physics and

542 Chemistry of the Earth 37-39: 10-17. doi:10.1016/j.pce.2011.12.002

543

544 Servicio Meteorologico Nacional. 2015. http://smn.cna.gob.mx/index.php?option $=$ com_content\&view $=$ article\&id $=42 \&$ Itemid $=28$ Accessed 20 October 2015

548 Silvertown J, Charlesworth D. 2007. Introduction to plant population biology. Ed. Blackwell 549 Publishing, $347 \mathrm{p}$.

550

551 Shreve F, Wiggins I. 1964. Vegetation and Flora of the Sonoran desert. Stanford University 552 Press, Stanford. 
554 Smith RAH, Bradshaw AD. 1979. The use of metal tolerant plant populations for the reclamation

555 of metalliferous wastes. Journal of Applied Ecology 16: 595-612. DOI: 10.2307/2402534

556

557 Solis-Dominguez FA, White SA, Hutter TB, Amistadi MK, Root RA, Chorover J, Maier RM.

558 2012. Response of key soil parameters during compost-assisted phytostabilization in 559 extremely acidic tailings: effect of plant species. Environmental Science and Technology

560 46: 1019-1027. DOI: 10.1021/es202846n

561

562 Sultan SA, Barton K, Wilczek AM. 2009. Contrasting patterns of transgenerational plasticity in 563 ecologically distinct congeners. Ecology 90: 1831-1839. DOI:10.1890/08-1064.1

564

565

566

567

United States Environmental Protection Agency (US-EPA), 1980. Method 6200: Solid and waste pH, en SW-846, Test Methods for Evaluating Solid Waste, Physical/Chemical Methods:

568

569

Verkleij, J A C, Golan-Goldhirsh A, Antosiewisz D M, Schwitzguebel J-P, Schroder P. 2009.

570

571 Dualities in plant tolerance to pollutants and their uptake and translocation to the upper plant parts. Environmental and Experimental Botany 67:10-22.

572 http://dx.doi.org/10.1016/j.envexpbot.2009.05.009

573 
574 Zas R, Cendan C, Sampedro L. 2013. Mediation of seed provisioning in the transmission of

575 environmental maternal effects in Maritime pine (Pinus pinaster Aiton). Heredity 111: 248-255.

576 DOI: $10.1038 / \mathrm{hdy} .2013 .44$

577

578

579

580

581 

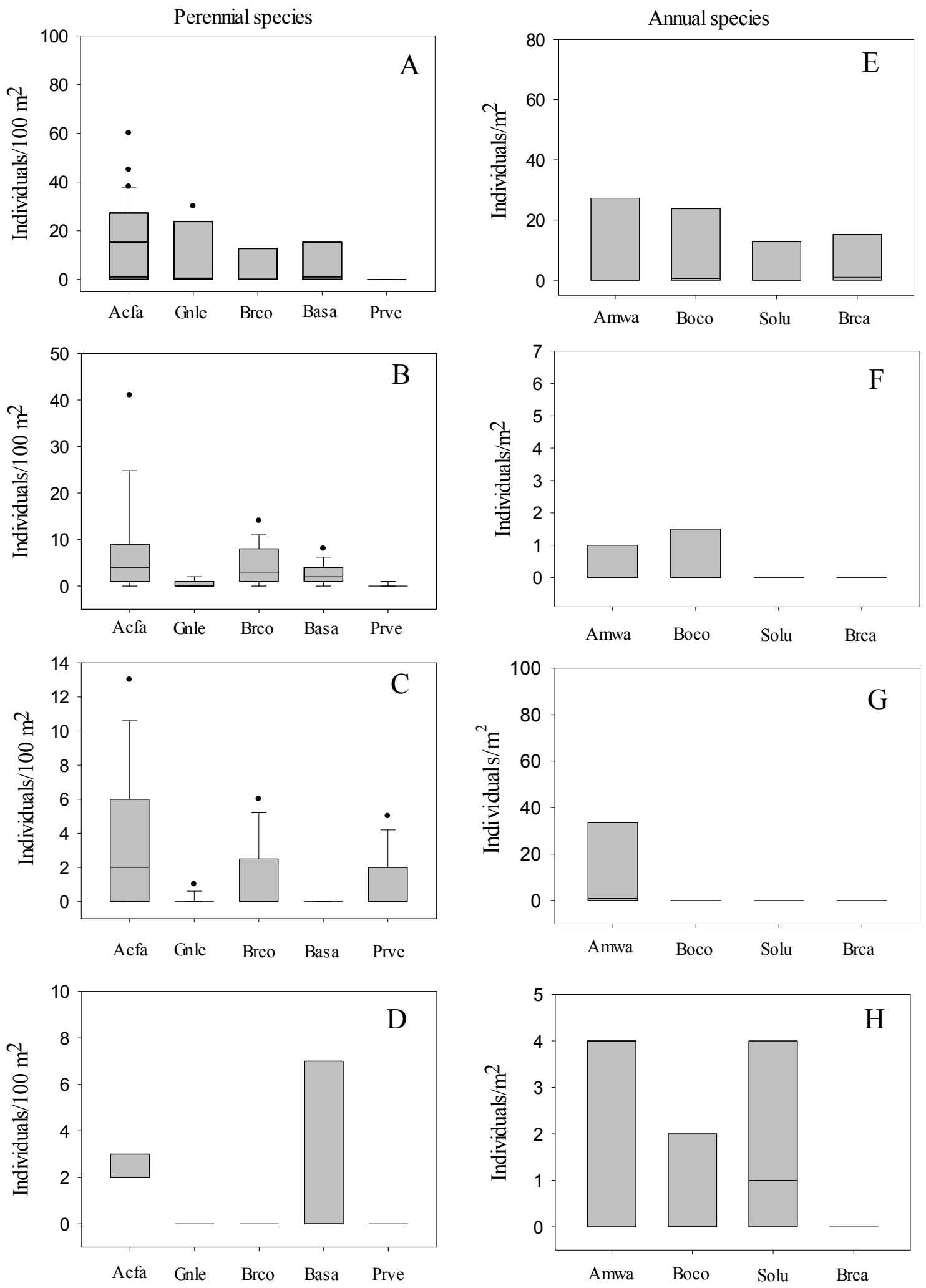
584 Figure 1. - Box plot of abundance of perennial (A-D) and annual (E-H) species recorded at four 585 patches in the central Nacozari tailings deposit. Boxes indicate the $25-75^{\text {th }}$ percentile, the line 586 within the box shows the median, error bars indicate the $90^{\text {th }}$ percentile and dots indicate 587 outlying points. 1A: patch 1; 1B: patch 2; 1C: patch 3; 1D: patch 4; 1E: patch 1; 1F: patch 2; 1G: 588 patch 3; 1H: patch 4. Perennial species; Acfa: Acacia farnesiana, Gnle: Gnaphalium 589 leucocephalum, Brco: Brickellia coulteri, Basa: Baccharis sarothroides and Prve: Prosopis 590 velutina. Annual species; Amwa: Amaranthus watsonii, Boco: Boerhavia coulteri, Solu: 591 Solanum lumholtzianum and Brca: Bromus catharticus. Notice that unit area is $100 \mathrm{~m}^{2}$ for 592 perennial species and $1 \mathrm{~m}^{2}$ for annual species. 

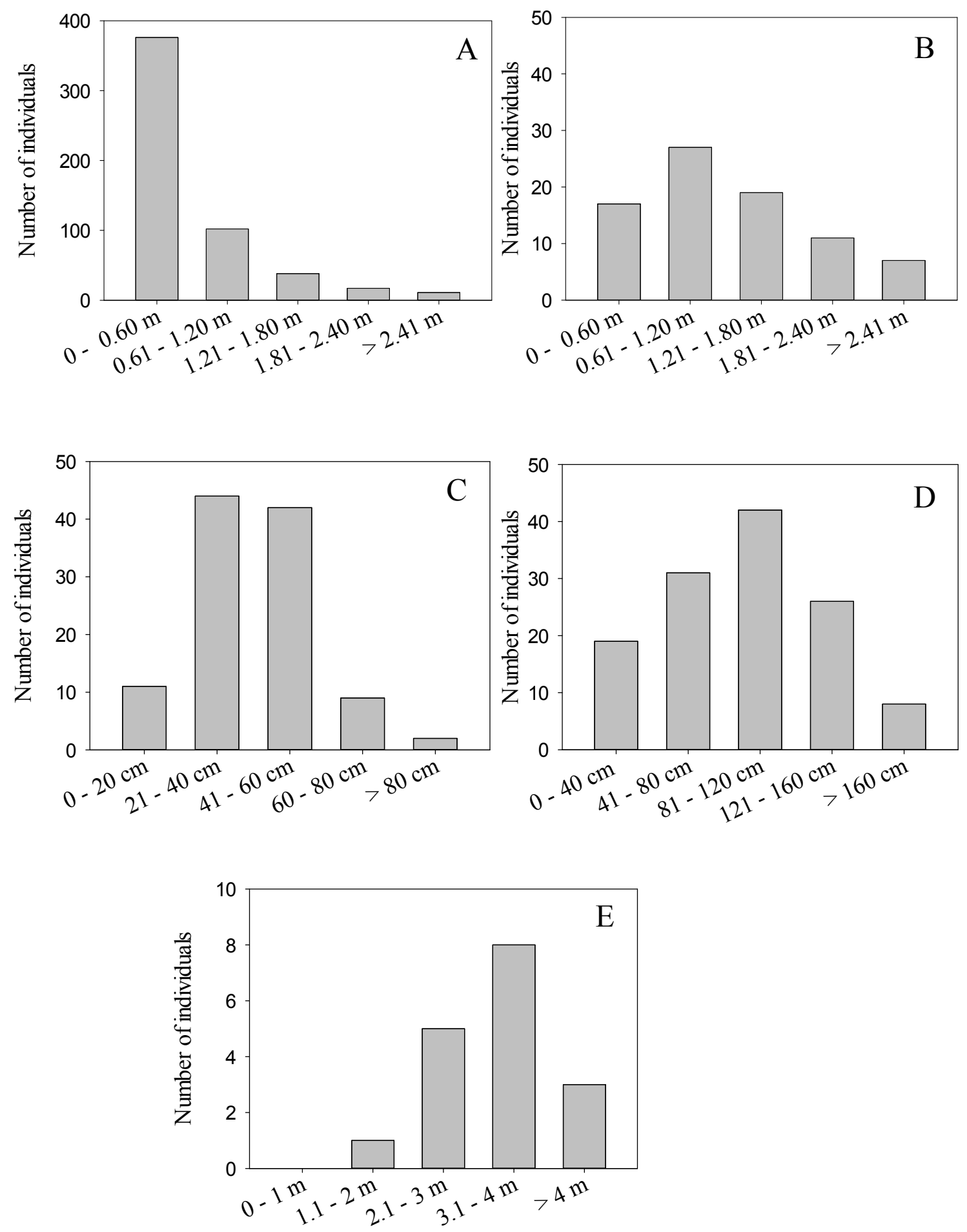

593 
599 Figure 2. - Population structure of the most common perennial species recorded at the center 600 Nacozari tailings deposit: 2A: Acacia farnesiana ( $\mathrm{n}=540$ individuals), 2B: Brickellia coulteri 601 ( $\mathrm{n}=126$ individuals), 2C: Baccharis sarothroides ( $\mathrm{n}=81$ individuals), 2D: Gnaphalium 602 leucocephalum ( $\mathrm{n}=108$ individuals), and 2E: Prosopis velutina $(\mathrm{n}=17$ individuals).

603

604

605

606

607 

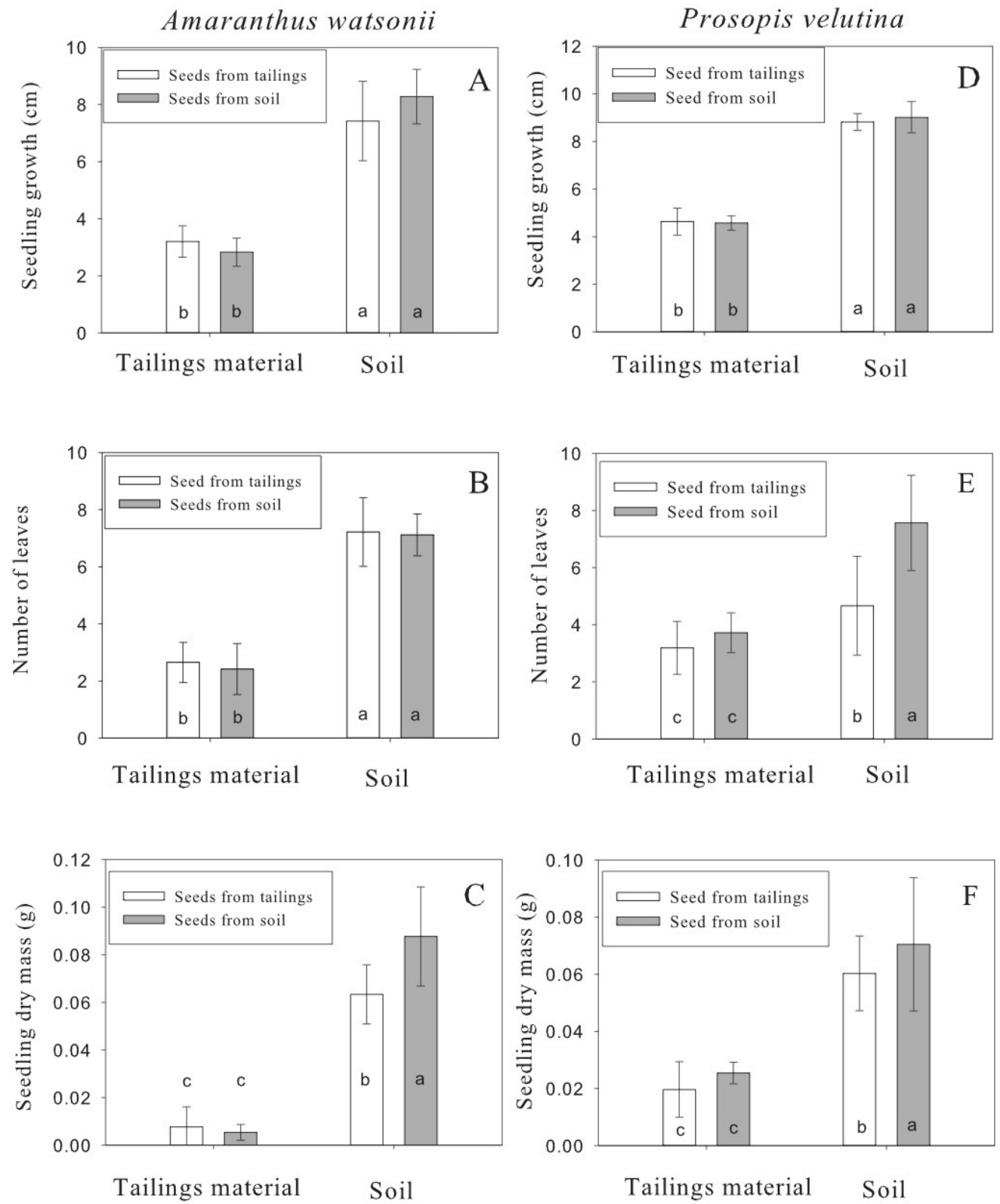

\section{GROWTH MEDIUM}


609

610

611

612

613

614

615

616

617

618

619

620

621

622

623
Figure 3. - Height (3A, 3D), number of leaves (3B, 3E) and total dry mass (3C, 3F) of seedlings of Amaranthus watsonii (3A, 3B, 3C) and Prosopis velutina (3D, 3E, 3F) coming from two different sources (tailings and an adjacent site with normal soil) after 30 days of growth in tailing material and soil. Different letters indicate significant differences. 
Table 1. -Physicochemical properties (mean \pm standard deviation) of the central Nacozari tailing from patches with vegetation and adjacent areas with no vegetation.

\begin{tabular}{|l|l|l|l|l|l|}
\hline Property & Patch with & Area with no & Statistical & Significance & Adjusted $\mathrm{p}$ - \\
& vegetation & vegetation & test & & values* \\
\hline $\mathrm{pH}$ & $4.7 \pm 0.2$ & $4.5 \pm 0.3$ & $\mathrm{t}=0.97$ & $\mathrm{p}=0.18$ & 0.06 \\
\hline Electrical & & & & & \\
\hline conductivity $(\mu \mathrm{S} / \mathrm{cm})$ & & $112.9 \pm 10.3$ & $\mathrm{t}=1.06$ & $\mathrm{p}=0.19$ & 0.34 \\
\hline Percentage of sand & $77.8 \pm 4.5$ & $79.8 \pm 3.7$ & $\mathrm{t}=0.57$ & $\mathrm{p}=0.30$ & 0.66 \\
\hline Percentage of clay & $5.7 \pm 2.9$ & $6.1 \pm 2.0$ & $\mathrm{t}=0.19$ & $\mathrm{p}=0.57$ & 0.89 \\
\hline As $\left(\mathrm{mg} \mathrm{kg}{ }^{-1}\right)$ & & & & & \\
\hline Ba (mg kg-1) & $18.7 \pm 2.3$ & $21.0 \pm 1.9$ & $\mathrm{t}=0.88$ & $\mathrm{p}=0.79$ & 0.37 \\
\hline Ca (mg kg-1) & $1,091.5 \pm 46.8$ & $1,172.5 \pm 76.0$ & $\mathrm{t}=1.81$ & $\mathrm{p}=0.06$ & 0.22 \\
\hline
\end{tabular}




\begin{tabular}{|c|c|c|c|c|c|}
\hline $\mathrm{Cu}\left(\mathrm{mg} \mathrm{kg}^{-1}\right)$ & $333.0 \pm 96.3$ & $271.5 \pm 45.7$ & $\mathrm{t}=0.05$ & $\mathrm{p}=0.47$ & 0.94 \\
\hline $\mathrm{Fe}\left(\mathrm{mg} \mathrm{kg}^{-1}\right)$ & $\begin{array}{l}26,167.7 \pm \\
6,454.6\end{array}$ & $\begin{array}{l}31,604.2 \pm \\
7,273.2\end{array}$ & $\mathrm{t}=1.32$ & $\mathrm{p}=0.88$ & 0.10 \\
\hline $\mathrm{K}\left(\mathrm{mg} \mathrm{kg}^{-1}\right)$ & $\begin{array}{l}35,741.2 \pm \\
1,247.6\end{array}$ & $\begin{array}{l}36,821.0 \pm \\
1,557.6\end{array}$ & $\mathrm{t}=2.25$ & $\mathrm{p}=0.03$ & 0.14 \\
\hline $\operatorname{Mn}\left(\mathrm{mg} \mathrm{kg}^{-1}\right)$ & $224.0 \pm 22.7$ & $225.7 \pm 11.9$ & $\mathrm{t}=0.81$ & $\mathrm{p}=0.77$ & 0.43 \\
\hline Mo $\left(\mathrm{mg} \mathrm{kg}^{-1}\right)$ & $57.2 \pm 15.8$ & $65.5 \pm 9.1$ & $\mathrm{t}=1.54$ & $\mathrm{p}=0.90$ & 0.22 \\
\hline $\mathrm{Pb}\left(\mathrm{mg} \mathrm{kg}^{-1}\right)$ & $32.7 \pm 6.5$ & $34.0 \pm 8.7$ & $\mathrm{t}=0.26$ & $\mathrm{p}=0.59$ & 0.81 \\
\hline $\mathrm{Rb}\left(\mathrm{mg} \mathrm{kg}^{-1}\right)$ & $259.0 \pm 9.1$ & $255.0 \pm 7.0$ & $\mathrm{t}=0.43$ & $\mathrm{p}=0.34$ & 0.75 \\
\hline $\mathrm{Sr}\left(\mathrm{mg} \mathrm{kg}^{-1}\right)$ & $94.2 \pm 22.5$ & $84.5 \pm 21.4$ & $\mathrm{t}=1.85$ & $\mathrm{p}=0.07$ & 0.28 \\
\hline $\mathrm{Ti}\left(\mathrm{mg} \mathrm{kg}^{-1}\right)$ & $1,536.0 \pm 208.7$ & $\begin{array}{l}1,394.5 \pm \\
176.4\end{array}$ & $\mathrm{t}=1.26$ & $\mathrm{p}=0.12$ & 0.20 \\
\hline $\mathrm{Zn}\left(\mathrm{mg} \mathrm{kg}^{-1}\right)$ & $69.0 \pm 3.4$ & $68.7 \pm 1.9$ & $\mathrm{t}=0.64$ & $\mathrm{p}=0.27$ & 0.64 \\
\hline
\end{tabular}




\begin{tabular}{|l|l|l|l|l|l|}
\hline $\mathrm{Zr}\left(\mathrm{mg} \mathrm{kg}^{-1}\right)$ & $142.7 \pm 4.8$ & $136.2 \pm 3.6$ & $\mathrm{t}=1.83$ & $\mathrm{p}=0.06$ & 0.28 \\
\hline
\end{tabular}

Multiple testing correction using Bonferroni (R Core Team, 2013).

Table 2. -Metal accumulation factors (mean \pm standard deviation) of the most abundant perennial species in the center tailing of

631 Nacozari. Accumulation factors are calculated as element concentration in leaves/element concentration in the rhizosphere.

\begin{tabular}{|l|c|c|c|c|c|}
\hline Plant & & & & & \\
species & Baccharis & Gnaphalium & Brickellia & Acacia & Prosopis \\
& sarotroides & leucocephalum & coulteri & farnesiana & velutina \\
\cline { 1 - 3 } & & & & & \\
\hline
\end{tabular}




\begin{tabular}{|c|c|c|c|c|c|}
\hline $\mathrm{Cu}$ & $0.26 \pm 0.10$ & $0.8 \pm 0.31$ & $0.22 \pm 0.08$ & $\begin{array}{c}0.44 \pm \\
0.15\end{array}$ & $\begin{array}{c}0.51 \pm \\
0.24\end{array}$ \\
\hline $\mathrm{Fe}$ & $\begin{array}{c}0.006 \pm \\
0.002\end{array}$ & $0.13 \pm 0.06$ & $\begin{array}{l}0.01 \pm \\
0.005\end{array}$ & $\begin{array}{c}0.04 \pm \\
0.15\end{array}$ & $\begin{array}{c}0.05 \pm \\
0.02\end{array}$ \\
\hline $\mathrm{K}$ & $1.32 \pm 0.43$ & $2.35 \pm 0.56$ & $1.57 \pm 0.30$ & $\begin{array}{c}0.68 \pm \\
0.16\end{array}$ & $\begin{array}{c}0.63 \pm \\
0.32\end{array}$ \\
\hline $\mathrm{Mn}$ & 0 & $3.44 \pm 2.40$ & $1.25 \pm 0.65$ & 0 & 0 \\
\hline Mo & $0.23 \pm 0.06$ & $0.27 \pm 0.08$ & $0.19 \pm 0.05$ & $\begin{array}{c}0.26 \pm \\
0.06\end{array}$ & $\begin{array}{c}0.22 \pm \\
0.03\end{array}$ \\
\hline $\mathrm{Rb}$ & $0.24 \pm 0.08$ & $0.38 \pm 0.23$ & $0.21 \pm 0.07$ & $\begin{array}{c}0.21 \pm \\
0.03\end{array}$ & $\begin{array}{c}0.17 \pm \\
0.04\end{array}$ \\
\hline $\mathrm{Sr}$ & $0.58 \pm 0.62$ & $0.52 \pm 0.33$ & $0.51 \pm 0.13$ & $0.97 \pm 1.0$ & $2.20 \pm 1.9$ \\
\hline $\mathrm{Zn}$ & $\begin{array}{c}3.45 \pm 3.6 \\
*\end{array}$ & $9.11 \pm 8.5 *$ & $1.7 \pm 2.6$ & $1.6 \pm 1.9$ & $1.55 \pm 2.8$ \\
\hline
\end{tabular}




\begin{tabular}{|l|c|c|c|c|c|}
\hline $\mathrm{Zr}$ & $0.06 \pm 0.03$ & & $0.05 \pm$ & $0.07 \pm$ & $0.064 \pm$ \\
& & $0.11 \pm 0.03$ & 0.006 & 0.005 & 0.008 \\
& & & & & \\
\hline
\end{tabular}

Mean ratios (leaves/rhizosphere) for all species were evaluated using a $\chi^{2}$ test. Ratios that were significantly greater than 1 are indicated with an asterisk $(*)$. 